\title{
Solid Oxide Fuel Cells for Power Generation and Hydrogen Production
}

\author{
Nguyen Q. Minh \\ Fountain Valley, California 92708, USA \\ (Received September 9, 2009; Accepted October 24, 2009)
}

\begin{abstract}
Solid oxide fuel cells (SOFCs) have been under development for a variety of power generation applications. Power system sizes considered range from small watt-size units (e.g., 50-W portable devices) to very large multi-megawatt systems (e.g., 500-MW base load power plants). Because of the reversibility of its operation, the SOFC has also been developed to operate under reverse or electrolysis mode for hydrogen production from steam (In this case, the cell is referred to as solid oxide electrolysis cell or SOEC.). Potential applications for the SOEC include on-site and large-scale hydrogen production. One critical requirement for practical uses of these systems is long-term performance stability under specified operating conditions. Intrinsic material properties and operating environments can have significant effects on cell performance stability, thus performance degradation rate. This paper discusses potential applications of the SOFC/SOEC, technological status and current research and development (R\&D) direction, and certain aspects of long-term performance degradation in the operation of SOFCs/SOECs for power generation/hydrogen production.
\end{abstract}

Key words: Solid oxide fuel cells, Solid oxide electrolysis cells, Applications, Technological status, Performance degradation

\section{Introduction}

$\mathrm{S}$ olid oxide fuel cells (SOFCs) have received widening interest as an advanced energy technology in the last fifteen years. The attractive feature of the SOFC is its clean and efficient generation of electricity from a broad spectrum of practical fuels. ${ }^{1,2)}$ Because of its all solid-state construction (mainly ceramic or ceramic and metal) and high operating temperature (in the range of about $600^{\circ}$ to $1000^{\circ} \mathrm{C}$ ), the SOFC offers several key advantages including flexibility in cell/stack designs, multiple options in cell manufacturing, and multi-fuel capability. The SOFC have been considered for a wide range of power generation applications, from small watt-size portable devices to large multi-megawatt stationary power plants. The technology has made significant progress in recent years, especially for the planar SOFC design with a number of prototype system demonstrations. However, several critical issues need to be resolved before widespread use of the SOFC for power generation.

The SOFC is known to be reversible, i.e., it can be operated under dual modes: power generation mode and electrolysis mode. In power generation mode, the SOFC acts as a fuel cell and generates electricity by electrochemically combining fuel and oxidant. In reverse mode when power is applied to the cell, the SOFC acts as an electrolyzer (referred to as solid oxide electrolysis cell or SOEC) and pro-

Corresponding author: Nguyen Q. Minh

E-mail : nqminh1@gmail.com

Tel : +1-714-955-1292 Fax : +1-714-839-1634 duces chemicals such as hydrogen through steam electrolysis. Solid oxide cells can be developed for either power generation (SOFC) or hydrogen production (SOEC) or both operating modes (in the case, the cell is referred to as a reversible SOFC or RSOFC). A RSOFC is a single unit that operates efficiently in both power generation and hydrogen production modes. The SOEC/RSOFC has been considered for on site and large-scale hydrogen production. Multi-cell stacks have been built and operated to demonstrate efficient hydrogen production from steam.

This paper provides an overview of potential applications, technological status and recent $R \& D$ trends in the development of the SOFC and discusses certain aspects of longterm performance degradation in the operation of SOFCs/ SOECs for power generation/hydrogen production.

\section{Potential Applications}

\subsection{Power Generation}

Potential markets for the SOFC include portable, transportation, and stationary sectors. Examples of portable applications are 10 100 W soldier power and $500 \mathrm{~W}$ battery chargers. Examples of transportation applications are $5 \sim 50 \mathrm{~kW}$ automobile and truck auxiliary power units (APUs) and $500 \mathrm{~kW}$ APUs for aircrafts. Examples of stationary applications include $1 \sim 10 \mathrm{~kW}$ residential, $10 \mathrm{~kW}$ $1 \mathrm{MW}$ combined heat and power (CHP) and distributed generation (DG), and multi-MW base load power plants. Many of these applications have progressed to hardware demonstration and prototype stages while several applications, especially those with large power outputs, are at the concep- 


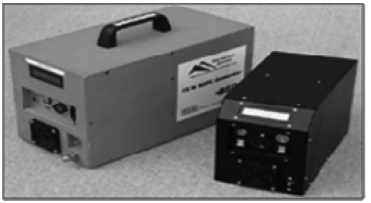

(a)

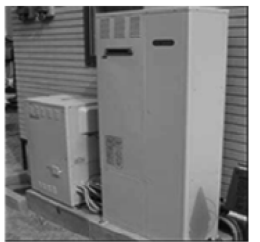

(c)

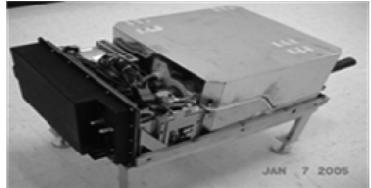

(b)

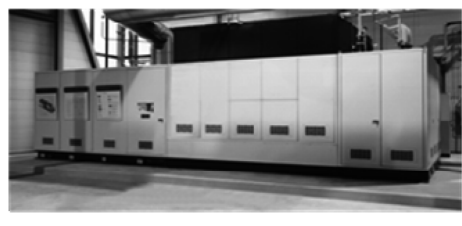

(d)
Fig. 1. Photographs of SOFC systems: (a) portable (Protonex), (b) automobile APU (Delphi), (c) residential (Kyocera), and (d) DG (Siemens).

Table 1. SOFC Applications

\begin{tabular}{|c|c|c|c|}
\hline Market & Application & Power Size & Status \\
\hline \multirow[b]{2}{*}{ Portable } & Soldier Power & $20 \sim 100 \mathrm{~W}$ & Demonstration \\
\hline & $\begin{array}{l}\text { Battery } \\
\text { Charger }\end{array}$ & $500 \mathrm{~W}$ & Demonstration \\
\hline \multirow[t]{2}{*}{ Transportation } & $\begin{array}{c}\text { Automobile } \\
\text { and Truck } \\
\text { APU }\end{array}$ & $5 \sim 50 \mathrm{~kW}$ & Demonstration \\
\hline & Aircraft APU & $\mathrm{Up}$ to $500 \mathrm{~kW}$ & Concept \\
\hline \multirow{3}{*}{ Stationary } & Residential & $1 \sim 5 \mathrm{~kW}$ & Prototype \\
\hline & $\mathrm{CHP}$ and $\mathrm{DG}$ & $10 \mathrm{~kW} \sim 1 \mathrm{MW}$ & $\begin{array}{c}\text { Demonstration } \\
\text { and concept }\end{array}$ \\
\hline & Base Load & 100 500 MW & Concept \\
\hline
\end{tabular}

tual stage. Examples of several SOFC system hardware and prototypes are given in Fig. $1 .^{3)}$ Table 1 summarizes the potential markets and technological status of each market for the SOFC.

For large $(>100 \mathrm{~kW})$ power plant applications indicated in Table 1, the SOFC can be configured in a simple cycle (i.e., the SOFC is the only power generating component) or integrated with a gas turbine (GT) to form a so-called hybrid system. The SOFC/GT hybrid arrangement can be directly

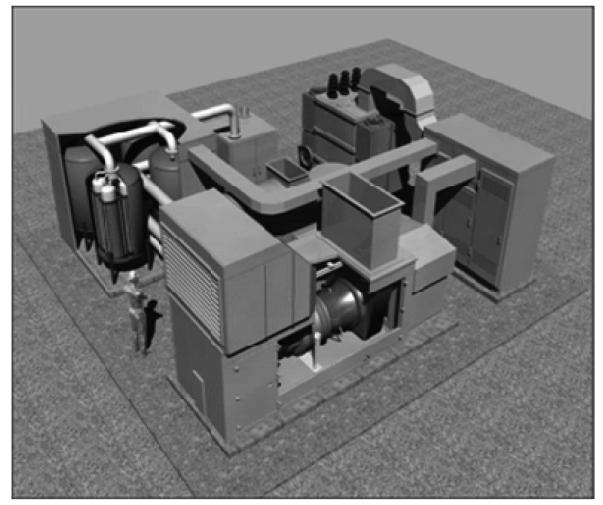

Fig. 2. Example of $5 \mathrm{MW}$ SOFC/GT hybrid system.
Table 2. Performance of SOFC Based Power Systems

\begin{tabular}{cccc}
\hline & Simple & Hybrid & $\begin{array}{c}\text { Hybrid with } \\
\text { Recycle }\end{array}$ \\
\hline Efficiency (\%) & 44.8 & 61.1 & 71.0 \\
SOFC Power* $(\mathrm{kW})$ & 3709 & 3709 & 4099 \\
GT Power* $(\mathrm{kW})$ & 0 & 976 & 1447 \\
Parasitic Power & $(389 \mathrm{~kW})$ & $(100 \mathrm{~kW})$ & $(288 \mathrm{~kW})$ \\
Net Plant Power & $3320 \mathrm{~kW}$ & $4585 \mathrm{~kW}$ & $5258 \mathrm{~kW}$ \\
SOFC Pressure & $1.3 \mathrm{~atm}$ & $4.6 \mathrm{~atm}$ & $4.6 \mathrm{~atm}$ \\
\hline
\end{tabular}

*After power conversion

- Natural gas

- 800C planar SOFC

fired or indirectly fired. ${ }^{4)}$ In the directly fired hybrid configuration, the residual fuel from the fuel cell is expanded through the gas turbine to produce additional electricity. In this case, the SOFC operates under pressure. In the indirectly fired hybrid configuration, the SOFC residual fuel passes through a recuperator to transfer energy to compressed air supply that in turn drives the turbine. This indirectly fired configuration decouples the turbine compressor pressure and the fuel cell operating pressure. The SOFC in this configuration can operate under ambient pressure. The SOFC/GT hybrid arrangement results in significant improvement in system efficiency; an example is shown in Table 2 for three systems: simple cycle, hybrid, and hybrid with gas recycle. Fig. 2 shows an example of a $5 \mathrm{MW}$ SOFC/ GT hybrid system concept. SOFC/GT hybrid systems can be further combined with gasifiers for operation on coal. Such a combined system - an integrated gasification fuel cell system or IGFC - has potential for overall efficiency from coal HHV (high heating value) to AC power on the order of $50 \%$ as shown in the example given in Fig. 3.

\subsection{Hydrogen Production}

The SOEC has been considered for on-site and large-scale hydrogen production and coproduction of electricity and hydrogen. One example of large-scale hydrogen production application is hydrogen by steam electrolysis using the SOEC with heat and electricity from nuclear power plants." One

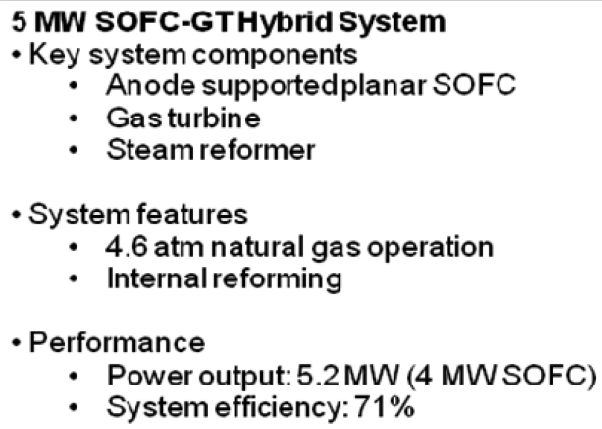



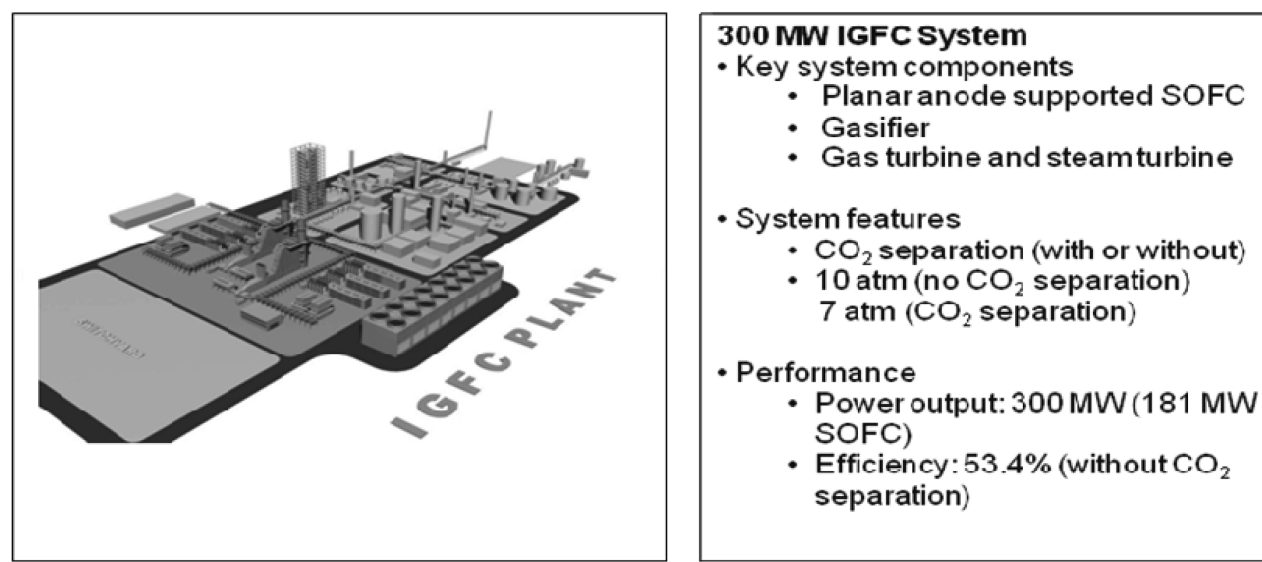

Fig. 3. Example of 300 MW IGFC system.

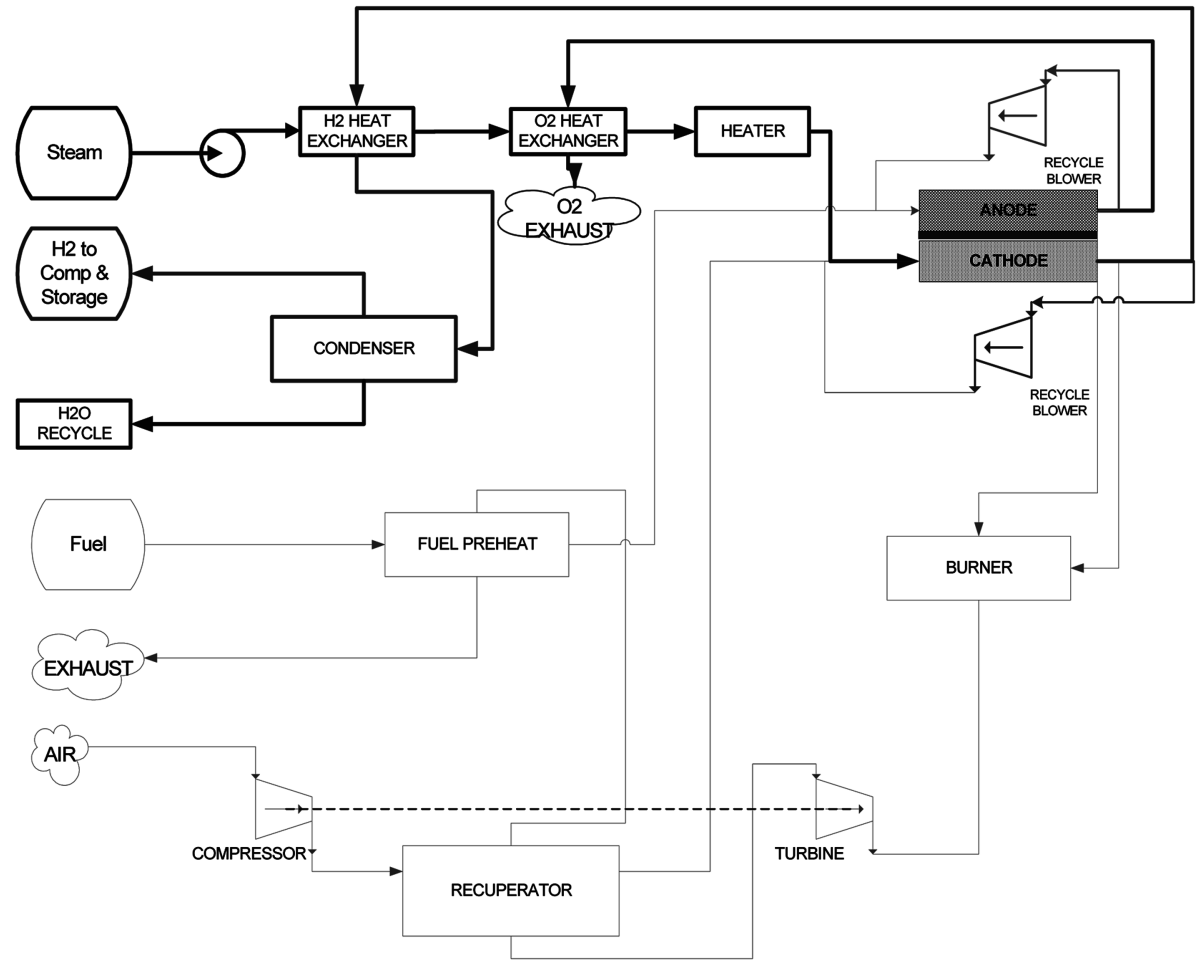

Fig. 4. Simplified schematic of RSOFC system.

example of on-site application is coproduction of electricity and hydrogen. With the SOFC+SOEC or RSOFC, a completely renewable production of electricity and hydrogen becomes possible when power generation and water or steam electrolysis are coupled. For instance, a renewable energy supply (e.g., solar, wind) can be used by the SOEC (or RSOFC in electrolysis mode) to produce hydrogen and oxygen from water. These chemicals can be used directly or stored for subsequent uses to produce electricity through the SOFC (or RSOFC in fuel cell mode). Similarly, the SOFC/RSOFC can generate electricity from biomass, and the electricity can then be used to produce hydrogen from steam electrolysis. A simplified schematic is given in Fig. 4 for a RSOFC system concept for on-site coproduction of electricity and hydrogen. ${ }^{6)}$

\section{Technology Progress and R\&D Direction}

\subsection{Power Generation}

Several technical issues have been identified and are being addressed in the development of SOFC products for practical applications. These issues mainly relate to the two drivers to enable commercialization: competitive cost and reliable performance with desired operating characteristics. The focus of current R\&D efforts is briefly discussed here:

(i) Materials: Recent activities on SOFC materials have been concentrated on three areas: metallic interconnects, seals, and high-performance cathodes.

- Work on metallic interconnects aims at resolving the issues of chromium vaporization and poisoning. Significant 


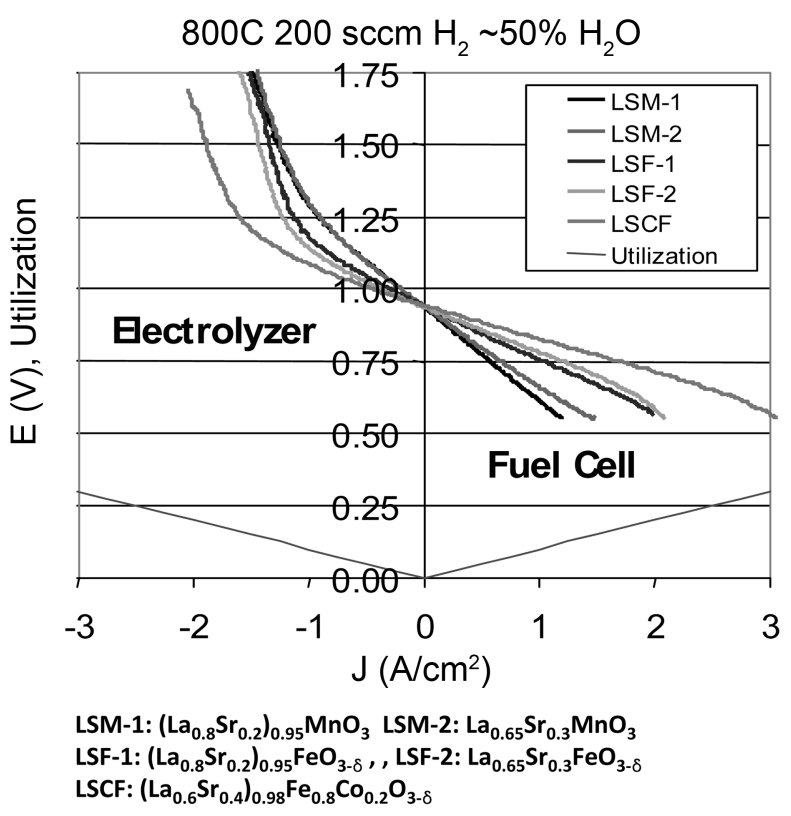

Fig. 5. Performance comparison of perovskite electrodes.

progress has been made in this area including the development of base materials (e.g., SS 441), material/surface modifications and protective coatings ( $\mathrm{Mn}$, Co spinel).

- Work on seals focuses on developing suitable materials based on glasses or glass composites for planar SOFCs. The key challenges involve both engineering and material developments to improve sealing properties and minimize elemental migration and interaction during long-term operation.

- Work on cathodes concentrates on developing high-performance materials with improved stability, especially to chromium poisoning. Present emphasis is placed on evaluating mixed conducting perovskites such as lanthanum strontium cobalt iron oxides. This class of materials has been shown to have low polarization, thus improved performance.
Fig. 5 demonstrates better performance of a LSCF electrode as compared to that of doped $\mathrm{LaFeO}_{3}$ (LSF) and $\mathrm{LaMnO}_{3}$ (LSM) in both fuel cell and electrolysis operation modes. ${ }^{6}$ )

(ii) Cells: The anode-supported cell configuration is most commonly used for planar SOFCs. In recent years, metallicsupported cell configuration and microtubular cell design have also been developed. One of the key challenges in SOFC cell development is scale-up to produce large area planar cells. To date, planar cells up to $40 \mathrm{~cm}$ diameter have been fabricated. In another cell design development, the sealless tubular has received a major design modification (flattenned tube) to improve performance and power density.

(iii) Stacks: Work on stacks involves improving and demonstrating required operating characteristics under practical conditions. This includes activities to improve stack performance by minimizing stack cathode polarization and contact losses. Both fundamental and engineering approaches (from determining and clarifying cathode reaction mechanisms to modifying cathode structures using infiltration). ${ }^{78}$ Other activities address life/degradation, thermal cycle/thermal management, and contaminant issues including contaminants from coal gases.

(iv) Systems: Significant progress has been made in demonstrating operation of SOFC systems, especially $10 \mathrm{~W}$ to $100 \mathrm{~W}$ portable and $\mathrm{kW}$-class systems based on planar stack designs. High system efficiency (in the order of 50\%) and long-term operation (up to several thousands of hours) have been established. An example of recent demonstration of $5 \mathrm{~kW}$ SOFC system is given in Fig. 6. ${ }^{9)}$ Several SOFC based system concepts such as SOFC/gas turbine (GT) hybrid and integrated gasification fuel cell (IGFC) as discussed earlier have been advanced.

\subsection{Hydrogen Production}

Recent development efforts on the SOEC/RSOFC have concentrated on evaluating cell and stack performance and operation characteristics using planar designs at operating

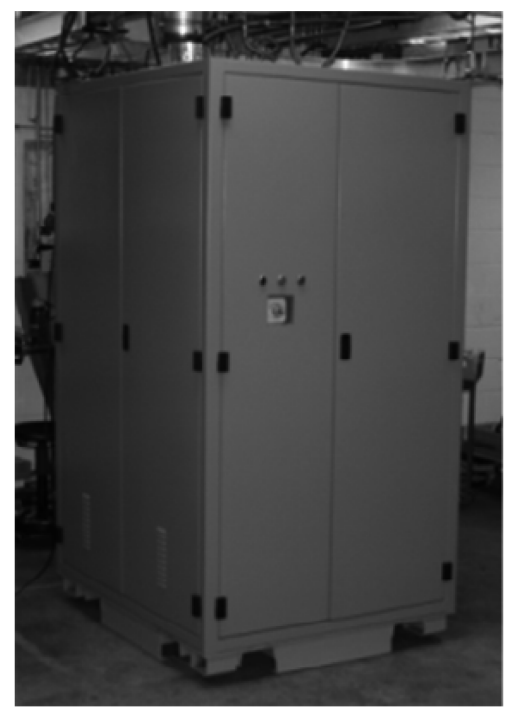

RESULTS

-Peak efficiency $49 \%$

- Net DC power $3.2 \mathrm{~kW}$

- Autothermal Reforming (ATR) fuel

- Fuel utilization $80 \%$

- Air utilization $24 \%$

- Peak power of $5.6 \mathrm{~kW}$

- Efficiency of $32 \%$

- ATR fuel

- Fuel utilization $65 \%$

- Air utilization $21 \%$

Fig. 6. 5-kW SOFC system. 


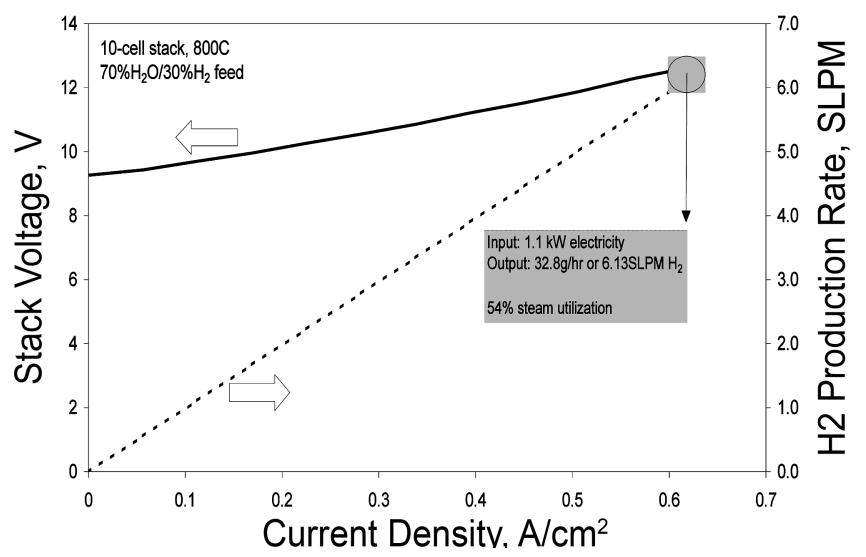

Fig. 7. Performance of a 10-Cell SOEC stack.

temperatures of $\leq 800^{\circ} \mathrm{C}$. To date, planar cells as large as $15 \mathrm{~cm}$ diameter and stacks as tall as sixty-cell height have been fabricated and tested. Excellent performance and efficient operation have been demonstrated for SOECs. For example, an area specific resistance (ASR) of about $0.22 \Omega \cdot \mathrm{cm}^{2}$ at $1.3 \mathrm{~V}$ cell voltage has been obtained for SOEC $2.5 \mathrm{~cm}$-button cells (with yttria-stabilized zirconia or YSZ electrolyte, Ni/YSZ hydrogen electrode and LSCF oxygen electrode) at $800^{\circ} \mathrm{C}$ with $\mathrm{H}_{2} / 80 \% \mathrm{H}_{2} \mathrm{O}$.using Au current collectors. ${ }^{6)}$ Fig. 7 shows an example of the performance of a 10-cell SOEC stack. As shown in the figure, at an average cell voltage of $1.26 \mathrm{~V}$, current density of $0.62 \mathrm{~A} / \mathrm{cm}^{2}$ and steam utilization of about 54\%, the stack generated 6.13 SLPM (Standard liter per minute) hydrogen with about $1.1 \mathrm{~kW}$ DC power input.

\section{Performance Degradation}

\subsection{Performance Degradation in SOFCs}

All-ceramic SOFC stacks when properly designed and prepared using appropriate materials tend to show little performance degradation in long-term operation. On the other hand, significant performance degradation has been observed in SOFCs, especially planar stacks with metallic interconnects. Two major root causes have been identified for observed long-term degradation: chromium poisoning of the cathode or oxygen electrode and increased ohmic and contact losses

- Chromium poisoning of SOFC cathodes (or oxygen electrodes): The vaporization and migration of chromium species (from $\mathrm{Cr}$ containing interconnects) and the deleterious effects of $\mathrm{Cr}$ poisoning on increased polarization losses of oxygen electrodes are well known and have been extensively studied in SOFCs. Significant progress has been made in this area including the development of base materials (e.g., SS 441), material/surface modifications and protective coatings (Mn, Co spinel). Fig. 8 shows, as an example, improved degradation rates of an SOFC using spinel-coated stainless steel interconnects. ${ }^{\text {9) }}$

- Increased ohmic contact losses at the electrode/interconnect interface: The contact between the ceramic electrode, especially the cathode and the metallic interconnect tends to

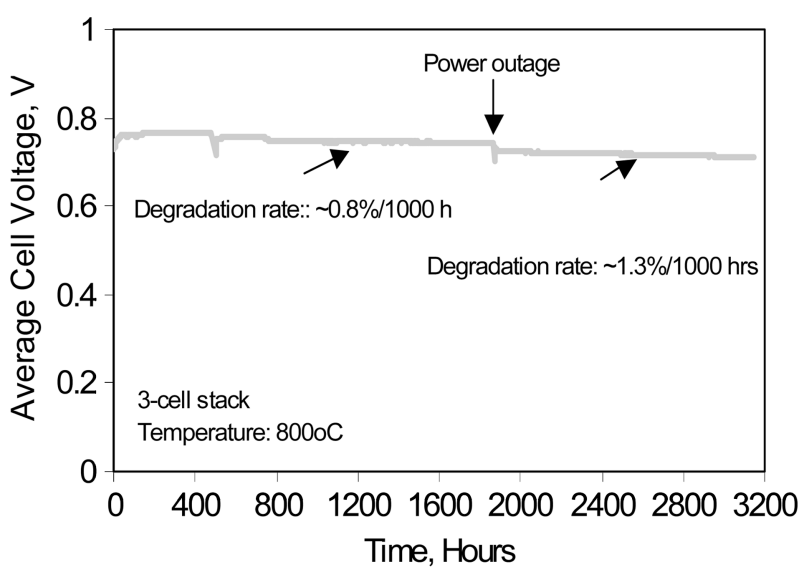

Fig. 8. Degradation rate of a SOFC stack with spinel-coated interconnects.

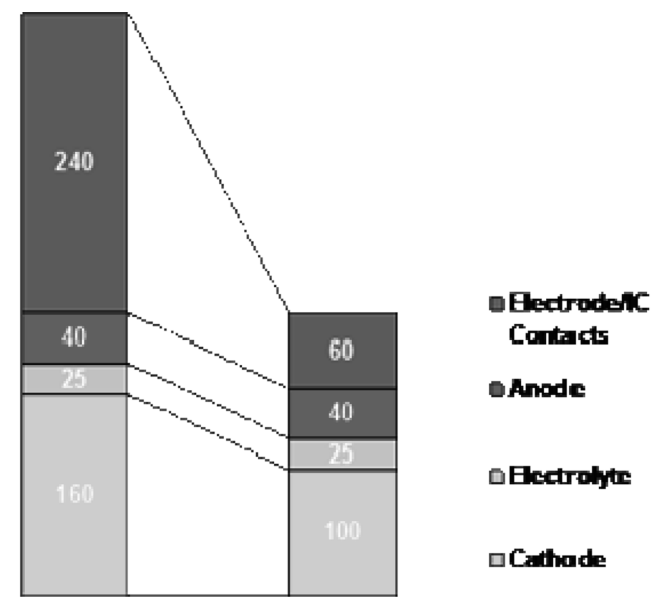

\section{$0.36 \mathrm{~W} / \mathrm{cm}^{2} \quad 0.75 \mathrm{~W} / \mathrm{cm}^{2}$}

Fig. 9. Area specific resistance breakdown $\left(m o h m-\mathrm{cm}^{2}\right)$ for a planar stack $\left(800^{\circ} \mathrm{C}, 0.75 \mathrm{~V}, 80 \%\right.$ Fuel Utilization).

change due to thermodynamic driving forces and other operating characteristics such as temperature distribution, thermal expansion mismatch as operation proceeds These factors lead to observed degradation in long-term operation. The contribution of contact resistance to the degradation is not clearly identified even though contact changes can play a major role in degradation observed in SOFCs. There are indications from SOFC work that contact resistance between the electrodes and the metallic interconnect is a major factor in SOFC performance losses (Fig. 9) ${ }^{10)}$ and performance degradation. It is highly possible that during long term operation, chemical interaction develops and electrical contact between the oxygen electrode and the interconnect evolves, ohmic resistance increased and contact area reduced, resulting in higher ohmic losses and thus degradation.

\subsection{Performance Degradation in SOECs/RSOFCs}

Significant degradation in cell performance has been observed in operation, especially long-term operation, of SOECs. The degradation is especially considerable with 


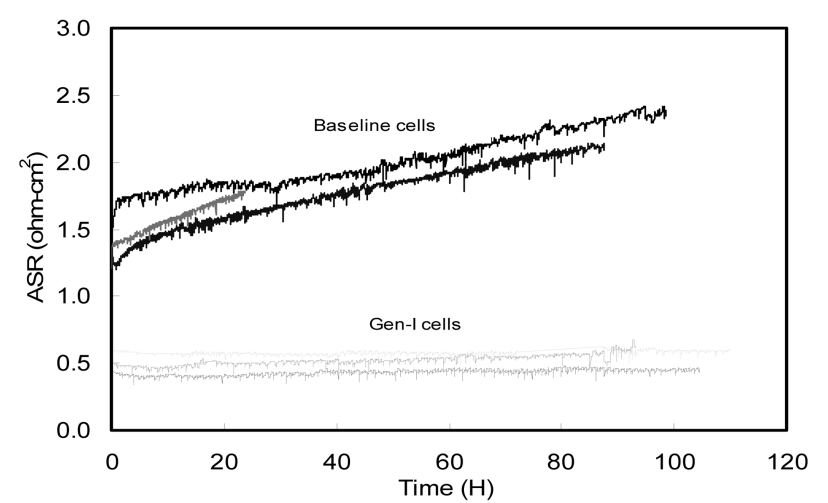

Fig. 10. ASR changes over time for cells with LSM/YSZ oxygen electrodes (Baseline) and LSCF electrodes (GenI) $\left(0.254 \mathrm{~A} / \mathrm{cm}^{2}, 800^{\circ} \mathrm{C}, 50 \% \mathrm{H}_{2} / 50 \% \mathrm{H}_{2} \mathrm{O}\right)$.

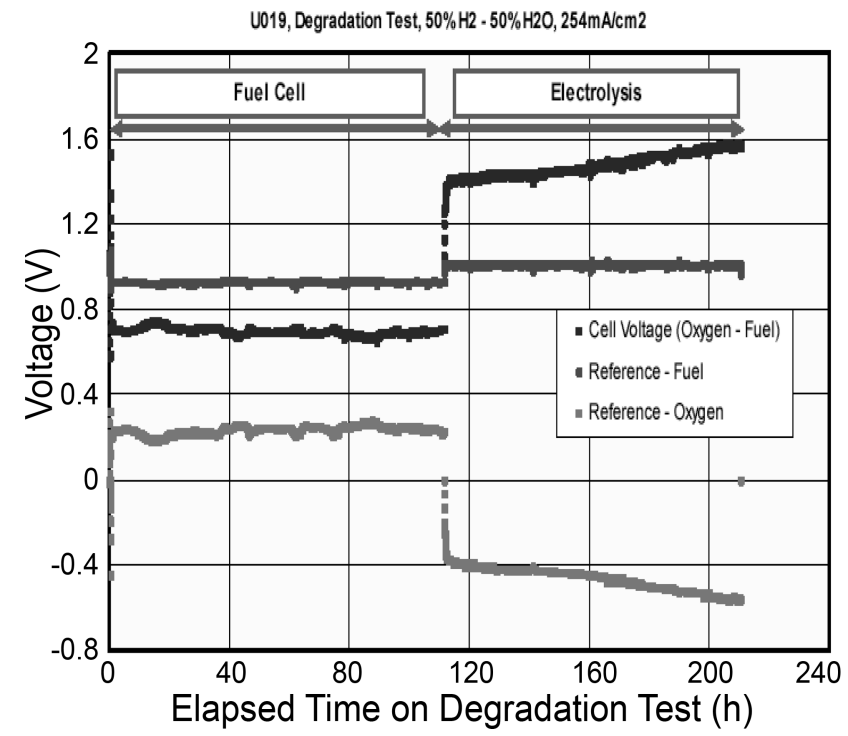

Fig. 11. Voltage changes observed in a single cell module (1Cell Stack).

purely electronic conducting oxygen electrodes (as compared to mixed conducting electrodes) (Fig. 10) and the observed degradation occurs mainly on the oxygen side in the electrolysis mode (Fig. 11). ${ }^{6}$

Work on SOEC modules (1-cell stacks) and multicell stacks reported a typical initial ASR of about $0.4 \mathrm{ohm}-\mathrm{cm}^{2}$ and a degradation rate of $0.2 \mathrm{ohm}-\mathrm{cm}^{2} / 1000 \mathrm{~h}\left(0.254 \mathrm{~A} / \mathrm{cm}^{2}\right.$, $\left.800^{\circ} \mathrm{C}, 50 \% \mathrm{H}_{2} / 50 \% \mathrm{H}_{2} \mathrm{O}\right)$. For LSCF oxygen electrodes and ferritic stainless steel (SS) interconnects and the following findings for stack long-term operation. ${ }^{6}$ )

- Use of coated stainless steel interconnects reduces performance degradation rates.

- Elemental migration occurs at oxygen electrode/interconnect interfaces and delamination at oxygen electrode/ electrolyte interfaces, especially with purely electronic conducting electrodes.

- ASR degradation rates under electrolysis mode at constant voltage of $1.3 \mathrm{~V}$ are comparable to those under fuel cell mode at constant voltage of $0.7 \mathrm{~V}$.

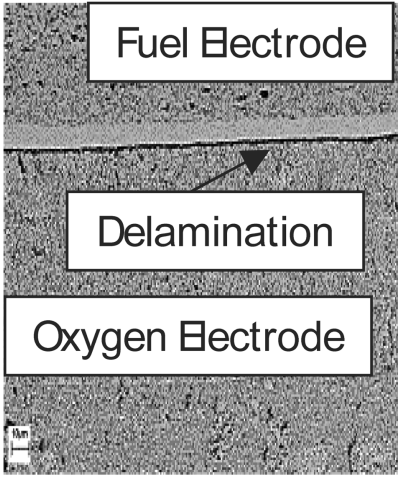

Fig. 12. Cross section of a tested SOEC cell showing delamination between LSM oxygen electrode and YSZ electrolyte. ${ }^{2)}$

Although stack performance degradation has been shown to take place predominantly on the oxygen side, the root causes for this degradation have not been clearly identified for the SOEC. The degradation on the oxygen electrode side can be due to several factors (as a function of operating time) or a combination of these factors:

(i) Increased polarization losses at the electrode (caused by poisoning e.g. Cr or electrode morphology changes) - The effects of chromium on polarization of SOEC oxygen electrodes are similar to those of SOFCs.

(ii) Delamination at the electrode/electrolyte interface With purely electronic conducting electrodes, oxygen is generated mainly at the electrode/electrolyte interface. This may lead to delamination (Fig. 12) induced by local pressure build-up. ${ }^{6}$ This type of delamination can be eliminated by using mixed conducting electrodes and modifying electrode microstructure to prevent oxygen accumulation and facilitate oxygen transport away from the interface.

(iii) Increased ohmic and/or contact losses at the electrode/ interconnect interface - The high oxygen activity and current flow (potential gradient) during electrolysis may promote the formation of resistive phases at the electrode/ interconnect interface. The behavior of the oxygen electrode/ metallic interconnect contact and contact evolution during long-term operation of the SOEC/RSOFC are similar to those discussed earlier for SOFCs.

\section{Conclusion}

The SOFC has the potential for a variety of power generation, hydrogen production and coproduction applications. The technology has made significant progress in the past few years with a number of SOFC power system prototype (up to several hundreds of $\mathrm{kW}$ output) demonstrations. Several critical issues including the issue of life/degradation have been identified. These issues (relating to competitive cost and reliable operation with desired performance characteristics) are the key drivers to commercialization of the SOFC and need to be resolved before widespread uses of the technology for power generation and/or hydrogen production. 


\section{Acknowledgments}

This paper has been prepared based on the results of the SOFC and RSOFC programs conducted at General Electric (GE) and supported by U.S. Department of Energy (DOE). The work was performed by the GE fuel cell team.

\section{REFERENCES}

1. N.Q. Minh, "Ceramic Fuel Cells," J. Am. Ceram. Soc., 76 [3] 563 (1993).

2. N.Q. Minh and T. Takahashi, Science and Technology of Ceramic Fuel Cells, Elsevier, Amsterdam, 1995.

3. N.Q. Minh, S.C. Singhal, and M.C. Williams, ECS Trans., in press.

4. National Energy Technology Laboratory, http://www.netl. doe.gov/technologies/coalpower/fuelcels/hybrids.html

5. C.M. Stoots, J.E. O'Brien, J.S. Herring, K.G. Condie, and J.J. Hartvigsen, in Proceedings of the 4th International
Topical Meeting on High Temperature Reactor Technology HTR2008, September 28-October 1, 2008, Washington, DC, HTR2008-58086 (2008).

6. J. Guan and N. Minh, High Performance Flexible Reversible Solid Oxide Fuel Cell Final Report, Report Number DOE/GO 14351, OSTI ID 899650, U.S. Department of Energy, Office of Science and Technical Information (2007).

7. K. Eguchi, S. C. Singhal, H. Yokokawa, and J. Mizusaki, Ed., SOFC-X, ECS Trans., Vol. 7, Issue 1, The Electrochemical Society, Pennington, NJ, 2006.

8. R. Steinverger-Wilckens, Ed., Proceedings of $8^{\text {th }}$ European SOFC Forum, European Fuel Cell Forum, Oberrohrdorf, 2008.

9. N.Q. Minh, "Coal Based Solid Oxide Fuel Cell Technology Development," ECS Trans.,7 [1] 45 (2006).

10. N.Q. Minh, "Cost, Performance, and Reliability of SOFC Systems," Proceedings of $8^{\text {th }}$ European SOFC Forum, B1303, European Fuel Cell Forum, Oberrohrdorf (2008). 